Article

\title{
Combating Desertification through the Wine Industry in Hongsibu, Ningxia
}

\author{
Liang Zhang ${ }^{1}$, Zhilei Wang ${ }^{1}$, Tingting Xue ${ }^{1,2}$, Feifei Gao ${ }^{1}$, Ruteng Wei ${ }^{1}$, Ying Wang ${ }^{1}$, Xing Han ${ }^{1}$, Hua Li ${ }^{1,3,4, *(D)}$ \\ and Hua Wang 1,3,4,* \\ 1 College of Enology, Northwest A\&F University, Yangling 712100, China; zhangliang20@nwafu.edu.cn (L.Z.); \\ wangzhilei@nwafu.edu.cn (Z.W.); xuetingting@nwafu.edu.cn (T.X.); gaofeifei@nwafu.edu.cn (F.G.); \\ weiruteng2019@nwafu.edu.cn (R.W.); wangying2018@nwafu.edu.cn (Y.W.); hanxing@nwafu.edu.cn (X.H.) \\ 2 School of Food \& Wine, Ningxia University, Yinchuan 750021, China \\ 3 Shaanxi Engineering Research Center for Viti-Viniculture, Yangling 712100, China \\ 4 China Wine Industry Technology Institute, Yinchuan 750021, China \\ * Correspondence: lihuawine@nwsuaf.edu.cn (H.L.); wanghua@nwsuaf.edu.cn (H.W.)
}

Citation: Zhang, L.; Wang, Z.; Xue, T.; Gao, F.; Wei, R.; Wang, Y.; Han, X.; Li, H.; Wang, H. Combating Desertification through the Wine Industry in Hongsibu, Ningxia. Sustainability 2021, 13, 5654. https:// doi.org/10.3390/su13105654

Academic Editor: Francesco Caracciolo

Received: 13 April 2021

Accepted: 13 May 2021

Published: 18 May 2021

Publisher's Note: MDPI stays neutral with regard to jurisdictional claims in published maps and institutional affiliations.

Copyright: (C) 2021 by the authors. Licensee MDPI, Basel, Switzerland. This article is an open access article distributed under the terms and conditions of the Creative Commons Attribution (CC BY) license (https:// creativecommons.org/licenses/by/ $4.0 /)$.

\begin{abstract}
Land desertification is a global environmental problem, leading to the deterioration of the ecological environment and is an issue that threatens humans. Hongsibu, located in Ningxia, northwest China, is a semi-desert area with the largest domestic single-site ecological resettlement area for poverty alleviation based on the wine industry. Here, we quantified the value of the ecosystem services of the wine industry in Hongsibu and used the analytic hierarchy process (AHP) to quantitatively evaluate the comprehensive benefits of the wine industry for resolving desertification. We found that winegrapes significantly increase vegetation cover, while significantly decreasing blowing sand and generating a total annual value of ecosystem services of $6.13 \times 10^{8} \mathrm{RMB}$. The evaluation score of the comprehensive benefits is $81.85 \%$, with grape growers and chateaus obtaining large economic benefits from the wine industry. In conclusion, the wine industry's development not only enhances the economic level of grape growers but significantly resolves desertification in impoverished areas-thus alleviating poverty and land degradation, contributing to sustainable development. Therefore, this may be an effective strategy for sustainable development in other parts of the world.
\end{abstract}

Keywords: wine industry; desertification; ecosystem services; economic benefits; sustainable development

\section{Introduction}

Land desertification is a global environmental problem that causes land degradation and ecological environment deterioration, and threatens humans. In China, desertified land areas extend over $2.61 \times 10^{6} \mathrm{~km}^{2}$, accounting for $1 / 4$ of its total land area. Nearly $40 \%$ of China's relatively poor counties and nearly $25 \%$ of the poor population are located in the desert area of northwest China. The Ningxia region is located in the eastern part of northwest China, at the upper and middle reaches of the Yellow River. Most of this region is arid and semi-arid, making it one of the most severely desertified northwest Chinese provinces. The desertified area extends for $2.9 \times 10^{6}$ ha-accounting for $55.8 \%$ of the total land area of Ningxia [1-3]. Poor people are directly affected by land desertification in Ningxia-raising serious concerns regarding how the people who live in these ecologically fragile areas can be fed, even while the goal of achieving a reduction in desertification is not prioritized [4].

Desertification has become a serious problem in the arid and semi-arid regions of northwest China [5-7]. Inadequate land management measures, especially overgrazing, remain the main cause of desertification in arid regions [8]. Several studies have determined the causes of land degradation and proposed governance measures [9]. Most of 
the government projects, such as the Three-North Shelterbelt System Project (since 1978) and the Ningxia Food Project 2605 (1980-present), aim to promote effective measures for desertification control, including the prohibition of grazing in fenced grasslands. Moreover, sustainable water management is the main measure for combating desertification in northwest China [10]. Desertification can also be resolved through economic development [11]. However, desertification is increasing at an alarming rate [8]; as such, residents in the affected areas cannot live while also protecting or improving the ecological environment [12]. The ineffectiveness of anti-desertification measures can be attributed to inadequate scientific involvement in decision-making, neglect of the human dimension, and a lack of a well-organized desertification monitoring system [13].

Hongsibu is a district of the Wuzhong Municipality, Ningxia, extending over an area of $2767 \mathrm{~km}^{2}$, and was a deserted area with an extremely undesirable ecological environment before the Hongsibu Development Zone was established in 1999. Land desertification has seriously affected the local ecological environment, socioeconomic development, and the quality of life here. To address this situation, large-scale desertification prevention works have been carried out in Hongsibu. Here, the key projects aim at returning farmlands to forests and at implementing economic forest construction [14]. Grapevines, as a type of economic forest, are typically representative of Hongsibu's characteristic economic forest industry. The vines can not only improve the local ecological environment but also address the problems of the area residents' income and poverty, achieving a win-win situation in terms of economic and ecological benefits.

In Hongsibu, farmers have been growing grapevines since 2007, leading to the development of the wine industry. The frequency of winegrape planting has increased, and investments in the construction of chateaus have achieved initial results after three years of initial development. In 2018, viticulture spanned over an area of 7067 ha in Hongsibu, with a preservation rate of $>70 \%$. So far, 30 registered enterprises have provided an important development platform for the wine industry here. The wine industry is based on wine grape cultivation and wine production and sale. Thus far, research on the wine industry has focused on wine grape cultivars [15], wine quality [16,17], anthocyanin [18], polymeric polyphenols [19], irrigation technology [20,21], fertilization management and soil types [22], biological control of crop pests [23], and wine regions [24]. At present, research into the sustainable development of the wine industry is focused on improving the grape production ecosystem - an extremely simplified ecological viticulture technology system, with grapevines shape control, comprehensive grassing, in-row canes coverage, and winter hanging canes [25]. However, research on the value of the wine industry, especially its ecological value, remains scant. The study of the ecological value of the wine industry can not only entail direct benefits to the industry itself, but also contribute to the achievement of ecological benefits.

This research aims, then, to understand the economic and ecological value of the wine industry. Based on this, we propose three hypotheses: (1) The Hongsibu's wine industry has great ecosystem services value. (2) This wine industry also has significant economic and social benefits. (3) The use of the analytic hierarchy process (AHP) to quantitatively analyze that the wine industry demonstrates considerable and comprehensive benefits of desertification control. Based on our results, we also propose important programs for similar areas in other parts of the world, which are currently encountering the dual pressure of poverty and environmental degradation. Our results are of great significance and can help comprehensively achieve the sustainable development of the wine industry as well as to provide a theoretical basis for desertification control and poverty alleviation and sustainable development of ecological resettlement areas.

\section{Materials and Methods}

\subsection{Study Region}

This study was performed in Hongsibu (Figure 1)—the largest wine subarea in the eastern part of the Helan Mountains in China; this region belongs to the Ningxia Au- 
tonomous Region, which is one of the wine regions with nationally protected geographical indications. Before the development of the wine industry, this area was deserted [26]. Located between the Daluo, Yantong, and the Niushou Mountains, Hongsibu is a mountain basin, with an area of $2767 \mathrm{~km}^{2}$ and an altitude of 1240-1450 m, and has a typical temperate continental climate, which is dry and rainless throughout the year. There is also a large diurnal temperature difference, with an average annual precipitation of $251 \mathrm{~mm}$, an average annual evaporation of $2387 \mathrm{~mm}$, an average annual temperature of $8.7^{\circ} \mathrm{C}$, a daily temperature difference of $13.7^{\circ} \mathrm{C}$, a sum of accumulated effective temperatures $\left(\geq 10^{\circ} \mathrm{C}\right)$ of $>3200{ }^{\circ} \mathrm{C}$, a total of annual sunshine hours of $2900-3550 \mathrm{~h}$, and an average annual wind speed of $2.9-3.7 \mathrm{~m} / \mathrm{s}$. There are four types of soil in this region: lime calcareous soil, new accumulative soil, eolian sandy soil, and saline soil.

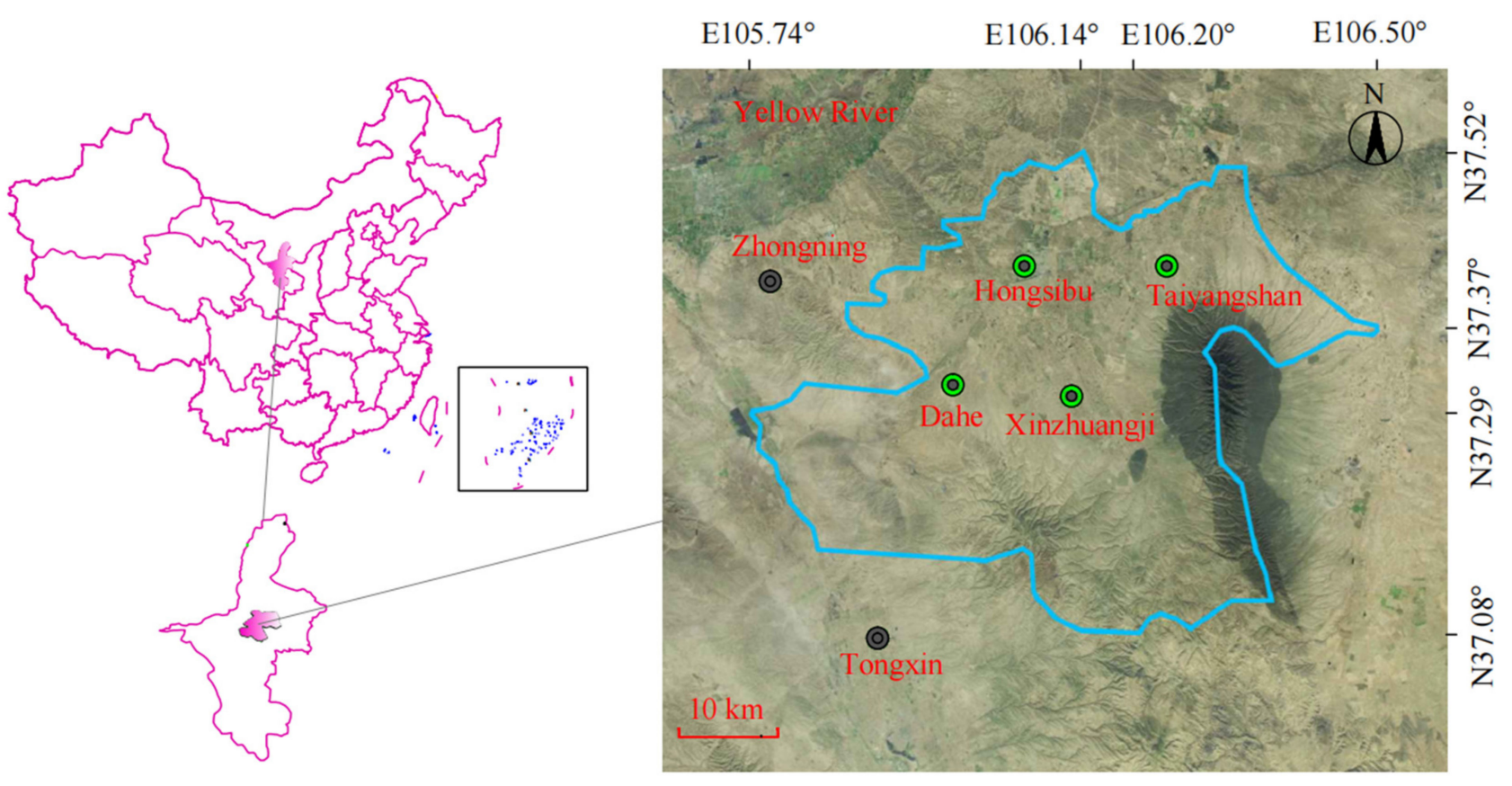

Figure 1. The study area: Hongsibu. The blue line represents the borders of Hongsibu. The survey sites selected for this study are marked in green (Grape growers Surveys, 2019 [n = 108] and Chateaus Surveys, 2019 [n = 10]).

\subsection{Hongsibu's Wine Industry for Combating Desertification}

The effect of the wine industry on desertification demonstrates the wine industry's value (i.e., ecological, economic, and social) as well as the comprehensive benefits of the wine industry against desertification (Figure 2). In March 2019, a one-week survey was conducted to obtain source data in Hongsibu. First, we studied the value of the wine industry by using the statistical methods for analyzing the original data. We then calculated the ecosystem services of the region (i.e., eastern foot of Helan Mountain, Ningxia, China) and Hongsibu. The ecosystem services, namely food production, carbon fixation, oxygen release, atmosphere purification, soil conservation, water conservation, water-saving and efficiency-enhancing, ecotourism, and ecological poverty alleviation [27], have been quantified using the method we used here [28-31]. The calculation formulas and the methods used for each value are shown in Table S1, see Supplementary Materials. Accordingly, we studied the comprehensive benefits of the wine industry for combating desertification. 


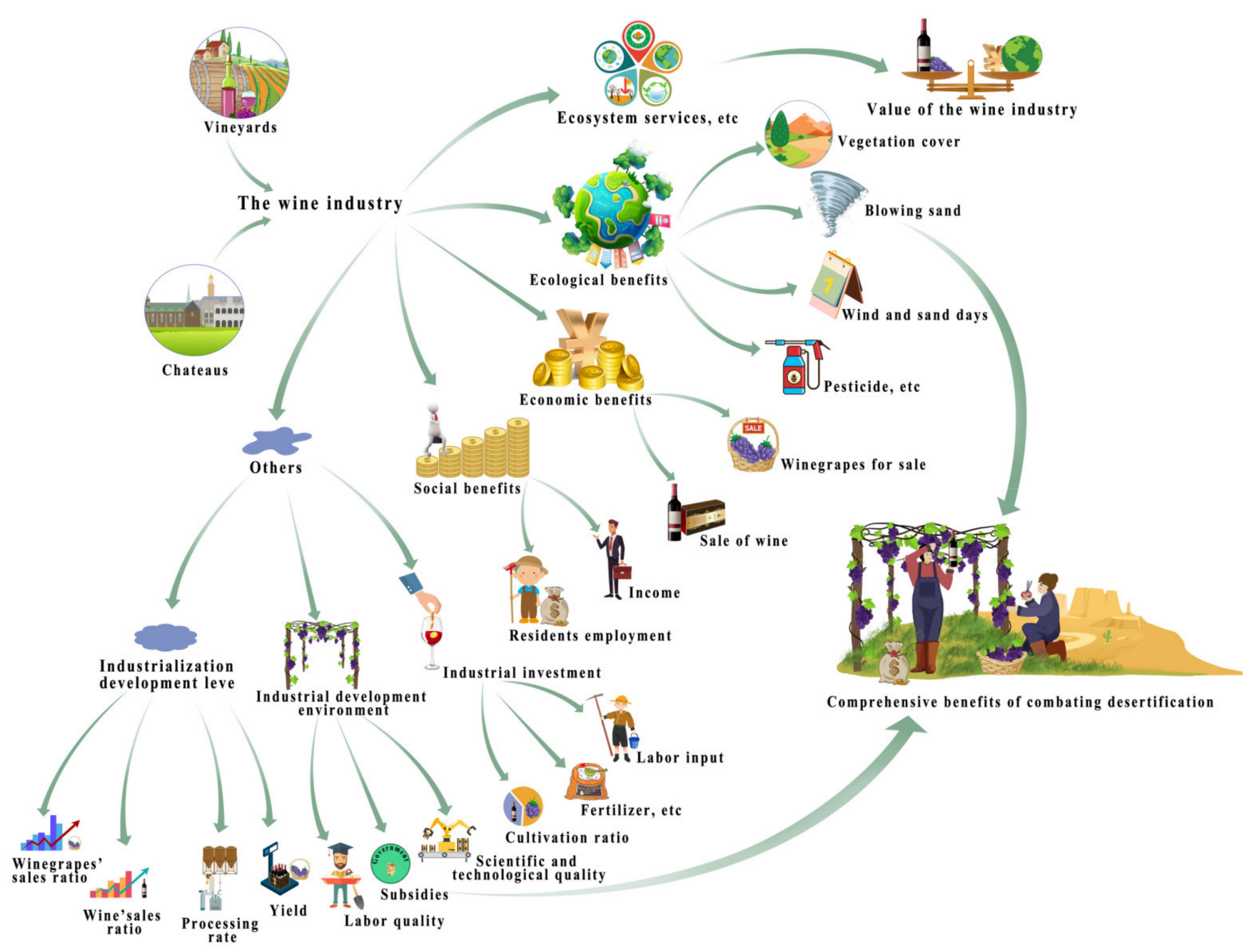

Figure 2. The wine industry's value and its comprehensive desertification control benefits.

\subsection{Evaluation of the Comprehensive Benefits}

Considering that the level of a technology can be considered a guarantee, economic, social, and ecological benefits can be classified as outputs. According to previous studies $[32,33]$, the comprehensive benefits of the wine industry for combating desertification should rely on stable farmers' investment levels and on a strong industrial development platform (depending on the winery) - taking the road of industrialization to realize economic, social, and ecological benefits synergistic.

\subsubsection{Construction of an Indicator System of the Comprehensive Benefits}

Only a few studies have developed an evaluation indicator system of the comprehensive benefits of the wine industry to combat desertification. By combining this with agricultural industry's evaluation indicator system for sustainable development [34,35], we constructed a framework of a system covering all aspects of the wine industry's first-level evaluation indicators: industrial investment, industrial development environment, industrialization development level, economic benefits, social benefits, and ecological benefits.

\subsubsection{Indicator Selection and Refinement}

As shown in Table 1, the various evaluation indicators of the framework were refined to form second-level indicators of evaluation indicator system for the comprehensive benefits of the wine industry to combat desertification. This refinement drew upon previous studies [36-39] and combined the wine industry's particularities. 
Table 1. Evaluation indicator system of comprehensive benefits of the wine industry to combat desertification.

\begin{tabular}{|c|c|c|c|c|}
\hline First-Level Indicators & Second-Level Indicators & Investigation Object & Formula & $\begin{array}{l}\text { Unit of } \\
\text { Measurement }\end{array}$ \\
\hline \multirow{3}{*}{ A Industrial investment } & $\begin{array}{l}\text { A1 Labor input of } \\
\text { unit area }\end{array}$ & Grape growers & $\mathrm{A} 1=$ labor input $/$ wine grapes area & $\begin{array}{l}\text { number of } \\
\text { people/ha }\end{array}$ \\
\hline & $\begin{array}{l}\text { A2 Amount of fertilizer } \\
\text { per unit area }\end{array}$ & Grape growers & $\begin{array}{l}\mathrm{A} 2=\text { fertilizing amount/wine } \\
\text { grapes area }\end{array}$ & $\mathrm{RMB} / \mathrm{ha}$ \\
\hline & A3 Planting ratio & Grape growers & $\begin{array}{l}\text { A3 = wine grapes area } / \text { total } \\
\text { cultivated area }\end{array}$ & $\%$ \\
\hline \multirow{3}{*}{$\begin{array}{l}\text { B Industrial } \\
\text { development } \\
\text { environment }\end{array}$} & $\begin{array}{l}\text { B1 Scientific and } \\
\text { technological quality }\end{array}$ & Grape growers & $\begin{array}{l}\text { B1 = scientific and technological } \\
\text { input/cost of investment }\end{array}$ & $\%$ \\
\hline & B2 Subsidies & Grape growers & $\begin{array}{l}\mathrm{B} 2=\text { government subsidies } / \text { cost of } \\
\text { investment }\end{array}$ & $\%$ \\
\hline & B3 Labor quality & Grape growers & $\begin{array}{l}\text { B3 = number of labor of middle } \\
\text { school or above/total labor }\end{array}$ & $\%$ \\
\hline \multirow{4}{*}{$\begin{array}{l}\text { C Industrialization } \\
\text { development level }\end{array}$} & C1 Yield per unit area & Grape growers & $\begin{array}{l}\mathrm{C} 1=\text { wine grapes yield } / \text { wine } \\
\text { grapes area }\end{array}$ & t/ha \\
\hline & C2 Wine grapes' sales rate & Grape growers & $\begin{array}{l}\mathrm{C} 2=\text { amount of wine grapes } \\
\text { sales/wine grapes yield }\end{array}$ & $\%$ \\
\hline & $\begin{array}{l}\text { C3 Enterprise processing } \\
\text { rate }\end{array}$ & Chateaus & $\begin{array}{l}\mathrm{C} 3=\text { amount of wine grapes } \\
\text { processing/wine grapes yield } \\
\text { of chateau }\end{array}$ & $\%$ \\
\hline & C4 Enterprise sales ratio & Chateaus & $\begin{array}{l}\mathrm{C} 4=\text { wine sales } / \text { total amount } \\
\text { of wine }\end{array}$ & $\%$ \\
\hline \multirow{2}{*}{ D Social benefits } & $\begin{array}{l}\text { D1Employment } \\
\text { proportion }\end{array}$ & Grape growers & $\begin{array}{l}\text { D1 = number of wine grapes } \\
\text { practitioners/agricultural } \\
\text { population }\end{array}$ & $\%$ \\
\hline & $\begin{array}{l}\text { D2 Poverty alleviation } \\
\text { ratio }\end{array}$ & Grape growers & $\begin{array}{l}\mathrm{D} 2=\text { number of poor } \\
\text { people/number of wine grapes } \\
\text { practitioners }\end{array}$ & $\%$ \\
\hline \multirow{3}{*}{ E Economic benefits } & $\begin{array}{l}\text { E1 Winegrapes contributes } \\
\text { to income }\end{array}$ & Grape growers & $\begin{array}{l}\text { E1 = wine grapes' income /farmer } \\
\text { income }\end{array}$ & $\%$ \\
\hline & $\begin{array}{l}\text { E2 Winegrapes' expected } \\
\text { contribution to income }\end{array}$ & Grape growers & $\begin{array}{l}\text { E2 = wine grapes' income at } \\
\text { expected maximum fruiting/farmer } \\
\text { income }\end{array}$ & $\%$ \\
\hline & $\begin{array}{l}\text { E3 Wine contributes to } \\
\text { chateau' income }\end{array}$ & Chateaus & $\mathrm{E} 3$ = wine income / investment cost & $\%$ \\
\hline \multirow{4}{*}{ F Ecological benefits } & $\begin{array}{l}\text { F1 The proportion of farm } \\
\text { manure used }\end{array}$ & Grape growers & $\begin{array}{l}\mathrm{F} 1=\text { farm manure usage } / \text { total } \\
\text { amount of fertilizer }\end{array}$ & $\%$ \\
\hline & $\begin{array}{l}\text { F2 Reduction rate of } \\
\text { desertified land }\end{array}$ & Chateaus & $\begin{array}{l}\text { F2 = wine growing area/land area } \\
\text { of chateau }\end{array}$ & $\%$ \\
\hline & $\begin{array}{l}\text { F3 Reduction rate of } \\
\text { windy and sandy days }\end{array}$ & Chateaus & $\begin{array}{l}\mathrm{F} 3=\text { reduced windy and sandy } \\
\text { days/total windy and sandy days } \\
\text { before the wine industry }\end{array}$ & $\%$ \\
\hline & $\begin{array}{l}\text { F4 Amount of pesticide } \\
\text { used per unit area }\end{array}$ & Grape growers & $\begin{array}{l}\mathrm{F} 4=\text { amount of pesticide used / wine } \\
\text { grapes area }\end{array}$ & $\mathrm{RMB} / \mathrm{ha}$ \\
\hline
\end{tabular}

\subsubsection{Determination of the Relative Weight of Indicators}

The evaluation indicator system comprises multiple evaluation indicators. The determination of the weight of the indicators is a key issue. Considering science and operability, and based on five experts' opinions, we determined the weight of each indicator [40]. We constructed a hierarchical structure model and used expert opinions and judgment matrices to compare indicators in pairs and determine their relative importance. Then, the indicators' relative weight was determined using MeshAHP software. 


\subsubsection{Data Standardization Processing}

By using the sampling survey method, we randomly selected 108 grape growers and 10 chateaus to obtain source data on evaluation indicators of the comprehensive benefits. The actual value of each indicator was then calculated using the formulas listed in Table 1. Because there were differences in data dimensions in the evaluation indicator system, the standard value method was used to standardize the indicators' actual values [36]. The treatment method employed is as follows: we conducted interviews with five experts, who were asked to evaluate each indicator, such that an appropriate standard value could be determined. We assumed the actual value $(\mathrm{Av})$ of the individual indicator and the standard value $(\mathrm{Sv})$ and calculated the standardized score of indicators: $\mathrm{S}=(\mathrm{Av} / \mathrm{Sv}) \times 100 \%$. Among the ecological benefits, the indicator of the amount of pesticide used per unit area is the inverse indicator. It was thus processed as $\mathrm{Sv} / \mathrm{Av}$. The standardized score value of each indicators were multiplied by the weight coefficient, which were then summed to calculate the comprehensive benefit for desertification control.

\section{Results}

\subsection{Changes in the Ecological Environment after the Wine Industry Development}

We can observe that wine industry development enabled the reduction of the desertified area. Before this development in 2007, Hongsibu was characterized by sparse vegetation, a forest cover of $<5 \%$, an extension of $2767 \mathrm{~km}^{2}$ of sand dunes, and a fragile ecological environment (Figure 3a). Since the development of the wine industry in 2007, viticulture area has been increasing so as to stop the expansion of deserts. Through wine industry development, special economic forests, such as grapevines, have been planted, with an extension of 11,733 ha being reached; this extension corresponded to an increase in the cover rate from $<5 \%$ to $10.35 \%$ of the total area. The ecological construction of the wine industry made significant results in Hongsibu, and the local ecological environment has undergone significant changes (Figure 3b).
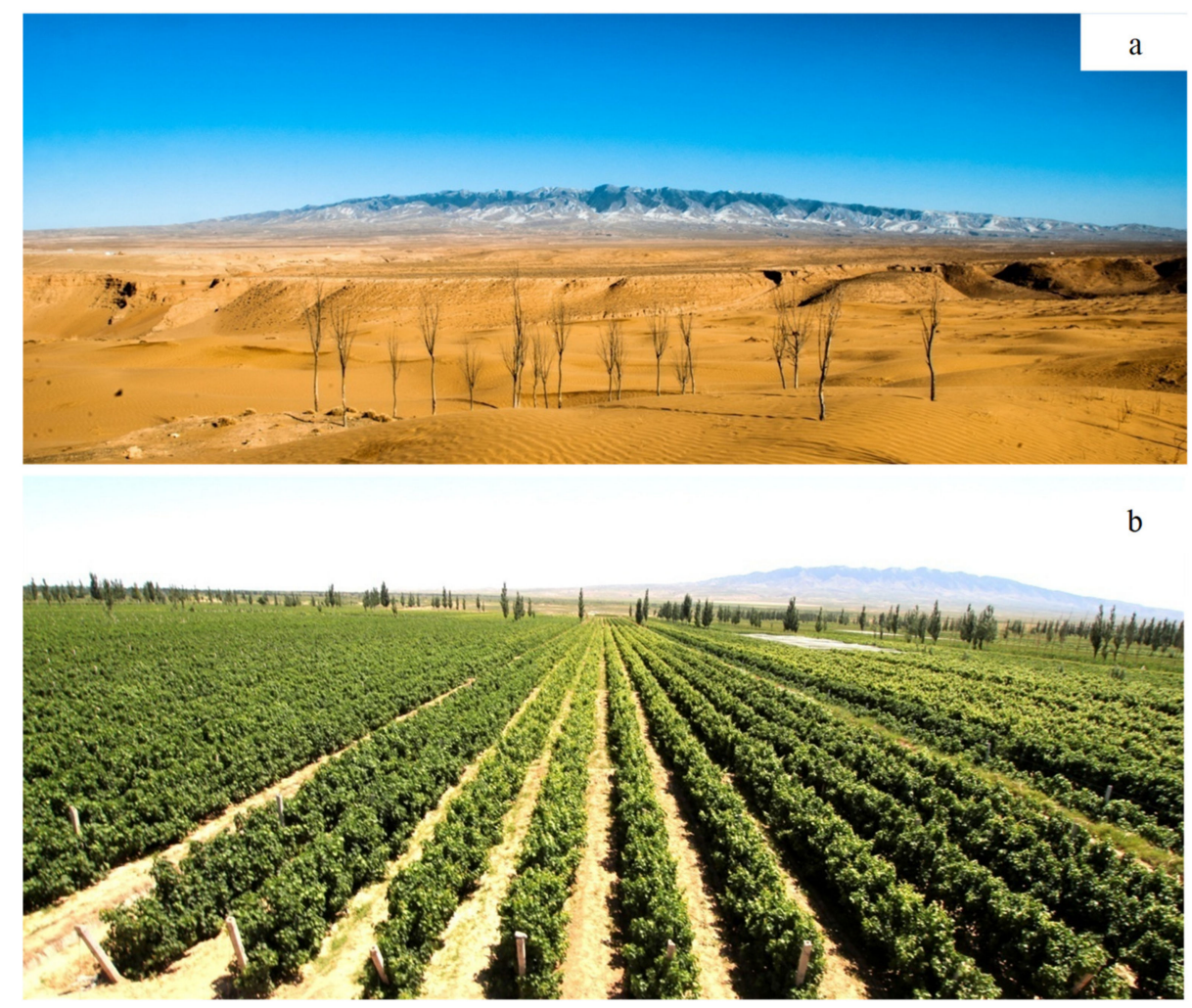

Figure 3. Ecological environment at the foot of Luoshan Mountain in Hongsibu (a) before and (b) after wine industry development. 
Because of increases in the economic forest area with grapevines, significant changes were noted in several aspects including an adjusted atmospheric climate and in reduced number of sandstorm and dusty days-from 35 days per year before the development of the wine industry to 10 days in 2013. After the wine industry development resolved desertification, the ecological environment underwent changes such as shrinkage of the sandy desertified land, the formation of a better microclimate environment, and the control of sand storm hazards.

\subsection{Ecosystem Services of the Wine Industry}

Wine grapes in the eastern foot of Helan Mountain have a large ecosystem services value, and the proportion of each function is similar to that of Hongsibu. Our results showed that the value of the ecosystem services of the wine industry in Hongsibu, from the highest to the lowest, was as follows: food production $>$ ecological poverty alleviation $>$ ecotourism $>$ atmospheric purification $>$ carbon sequestration and oxygen release $>$ water-saving and efficiency-enhancing $>$ soil conservation $>$ water resources conservation. In detail, the value of food production is $3.46 \times 10^{8} \mathrm{RMB}$, accounting for up to $54.96 \%$ of the total value; it is followed by the value of ecological poverty alleviation $\left(1.67 \times 10^{8} \mathrm{RMB}\right.$, accounting for $26.53 \%$ of the total value) and ecotourism $\left(6.36 \times 10^{7} \mathrm{RMB}\right.$, accounting for $10.10 \%$ of the total value; Table 2 ).

Table 2. Value of the ecosystem services of the wine industry.

\begin{tabular}{|c|c|c|c|c|c|}
\hline Ecological Function & Formulas & $\begin{array}{c}\text { Value of the Eastern Foot of } \\
\text { Helan Mountain } \\
\text { (RMB/Year) }\end{array}$ & $\begin{array}{l}\text { Proportion of Each } \\
\text { Function (\%) }\end{array}$ & $\begin{array}{l}\text { Value of Hongsibu } \\
\quad \text { (RMB/Year) }\end{array}$ & $\begin{array}{l}\text { Proportion of Each } \\
\text { Function (\%) }\end{array}$ \\
\hline Food production & $\mathrm{W}_{\mathrm{f}}=\mathrm{P} \cdot \mathrm{A}$ & $1.86 \times 10^{9}$ & 56.42 & $3.46 \times 10^{8}$ & 54.96 \\
\hline \multirow{3}{*}{$\begin{array}{c}\text { Carbon sequestration and } \\
\text { oxygen release }\end{array}$} & $\mathrm{CV}=\mathrm{Pc} \cdot \mathrm{N} \cdot \mathrm{A} \cdot a$ & $2.51 \times 10^{7}$ & \multirow{3}{*}{3.52} & $4.67 \times 10^{6}$ & \multirow{3}{*}{3.43} \\
\hline & $\mathrm{OV}=\mathrm{Po} \cdot \mathrm{N} \cdot \mathrm{A} \cdot b$ & $9.10 \times 10^{7}$ & & $1.69 \times 10^{7}$ & \\
\hline & $\mathrm{U}_{\mathrm{SO} 2}=\mathrm{K}_{\mathrm{SO} 2} \cdot \mathrm{Q}_{\mathrm{SO} 2} \cdot \mathrm{A}$ & $2.05 \times 10^{6}$ & & $3.82 \times 10^{5}$ & \\
\hline \multirow{3}{*}{ Atmospheric purification } & $\mathrm{U}_{\mathrm{NOx}}=\mathrm{K}_{\mathrm{NOx}} \cdot \mathrm{Q}_{\mathrm{NOx}} \cdot \mathrm{A}$ & $2.74 \times 10^{4}$ & \multirow{3}{*}{1.83} & $5.09 \times 10^{3}$ & \multirow{3}{*}{4.45} \\
\hline & $\mathrm{U}_{\mathrm{HF}}=\mathrm{K}_{\mathrm{HF}} \cdot \mathrm{Q}_{\mathrm{HF}} \cdot \mathrm{A}$ & $1.82 \times 10^{4}$ & & $3.39 \times 10^{3}$ & \\
\hline & $\mathrm{U}_{\mathrm{S}}=\mathrm{K}_{\mathrm{S}} \cdot \mathrm{Q}_{\mathrm{S}} \cdot \mathrm{A}$ & $5.81 \times 10^{7}$ & & $1.08 \times 10^{7}$ & \\
\hline \multirow{2}{*}{$\begin{array}{l}\text { Soil conservation } \\
\text { Water resources } \\
\text { conservation }\end{array}$} & $\mathrm{W}_{\mathrm{s}}=(\mathrm{A}-\mathrm{L}) \cdot \mathrm{C} \cdot \mathrm{P}$ & $5.65 \times 10^{6}$ & 0.17 & $1.05 \times 10^{6}$ & 0.17 \\
\hline & $\mathrm{W}_{\mathrm{w}}=(\mathrm{R}-\mathrm{E}) \cdot \mathrm{A} \cdot \mathrm{P}$ & $4.07 \times 10^{6}$ & 0.12 & $7.58 \times 10^{5}$ & 0.12 \\
\hline \multirow{3}{*}{$\begin{array}{l}\text { Water-saving and } \\
\text { efficiency-enhancing } \\
\text { Ecotourism } \\
\text { Ecological poverty } \\
\text { alleviation }\end{array}$} & $Q=(X-x) \cdot A \cdot P$ & $8.40 \times 10^{6}$ & 0.25 & $1.56 \times 10^{6}$ & 0.25 \\
\hline & $\mathrm{V}=\mathrm{P} \cdot \mathrm{N} \cdot \mathrm{Y}$ & $3.42 \times 10^{8}$ & 10.37 & $6.36 \times 10^{7}$ & 10.10 \\
\hline & $\mathrm{PA}=\mathrm{P} \cdot \mathrm{N}$ & $9.00 \times 10^{8}$ & 27.30 & $1.67 \times 10^{8}$ & 26.53 \\
\hline
\end{tabular}

The total value of ecosystem services of Hongsibu's the wine industry is $6.13 \times 10^{8} \mathrm{RMB}$. Among atmospheric purification, the value of dust and sand blocking is $1.08 \times 10^{7} \mathrm{RMB}$ (Table 2)-indicating that the wine industry has an important ecological value and plays an important role in atmospheric purification of ecological environment.

\subsection{Economic Benefits of the Wine Industry}

After 2010, as wine grapes entered the fruit-bearing period, both the yields and the planting income of farmers began increasing annually. The scale of viticulture expanded continuously in Hongsibu, from 5800 ha in 2014 to 7067 ha in 2018 (Table 3). Wine grapes yields, including the perunit and total yields, also increased annually. Resident income from winegrapes also increased annually - with the income per unit area increasing from $10,821.76 \mathrm{RMB} /$ ha in 2014 to $14,824.39 \mathrm{RMB} / \mathrm{ha}$ in 2018, and the agricultural per capita net income increasing from 1008.60 RMB in 2014 to 1399.80 RMB in 2018. During the same period, the proportion of wine grapes in per capita net income increased steadily, from $49.58 \%$ in 2014 to $68.50 \%$ in 2018 (Table 3). The wine industry depends on chateaus, and our analysis revealed the grape growers gained significant benefits from the sales of wine grapes, with a grape grower's average annual income being 40,000 RMB and the highest income of a single household being 200,000 RMB. The highest income exceeded 
$105,000 \mathrm{RMB} /$ ha- equivalent to 7-8 times that with corn. Our results thus indicated that winegrapes have a significant economic value with regard to the growers' income.

Table 3. Changes in production, sales, and income of wine grapes over 2014-2018.

\begin{tabular}{|c|c|c|c|c|c|c|c|}
\hline Year & $\begin{array}{c}\text { Cultivated Area } \\
\text { (ha) }\end{array}$ & Fruit Area (ha) & $\begin{array}{l}\text { Per Unit Yield } \\
(\mathrm{kg} / \mathrm{ha})\end{array}$ & Total Yield (t) & $\begin{array}{c}\text { Income Per Unit } \\
\text { Area (RMB/ha) }\end{array}$ & $\begin{array}{l}\text { Agricultural Per } \\
\text { Capita Net Income } \\
\text { (RMB) }\end{array}$ & $\begin{array}{l}\text { Proportion of Wine } \\
\text { Grapes in per Capita } \\
\text { Net Income (\%) }\end{array}$ \\
\hline 2014 & 5800 & 2578 & 3091.93 & 7971.00 & $10,821.76$ & 1008.60 & 49.58 \\
\hline 2015 & 5934 & 2680 & 3638.36 & 9750.80 & $11,642.75$ & 1093.20 & 58.54 \\
\hline 2016 & 6500 & 3300 & 3866.06 & $12,758.00$ & $12,758.00$ & 1185.50 & 60.46 \\
\hline 2017 & 7067 & 3265 & 3982.45 & $13,002.70$ & $13,938.58$ & 1286.70 & 65.78 \\
\hline 2018 & 7067 & 4150 & 4235.54 & $17,577.49$ & $14,824.39$ & 1399.80 & 68.50 \\
\hline
\end{tabular}

Sources: Hongsibu District Natural and Resources Bureau of Wuzhong Municipality, and Hongsibu District Agriculture and Rural Affairs Bureau of Wuzhong Municipality.

The wine production and sales also increased annually, from $3200 \mathrm{t}$ in 2014 to $9100 \mathrm{t}$ in 2018 and from $1000 \mathrm{t}$ in 2014 to $4500 \mathrm{t}$ in 2018, respectively (Figure 4a). Moreover, the value of wine sales increased annually, from $1.7 \times 10^{8} \mathrm{RMB}$ in 2014 to $3.5 \times 10^{8} \mathrm{RMB}$ in 2018. During the same period, the profits from wine sales increased annually, from $9.0 \times 10^{7} \mathrm{RMB}$ in 2014 to $2.1 \times 10^{8} \mathrm{RMB}$ in 2018 (Figure $4 \mathrm{~b}$ ). Thus, a strong and significant economic benefit of the wine industry was observed.

- Wine production / $\mathrm{t}$

- Wine sales $/ \mathrm{t}$

- Sales of wine / thousand bottles

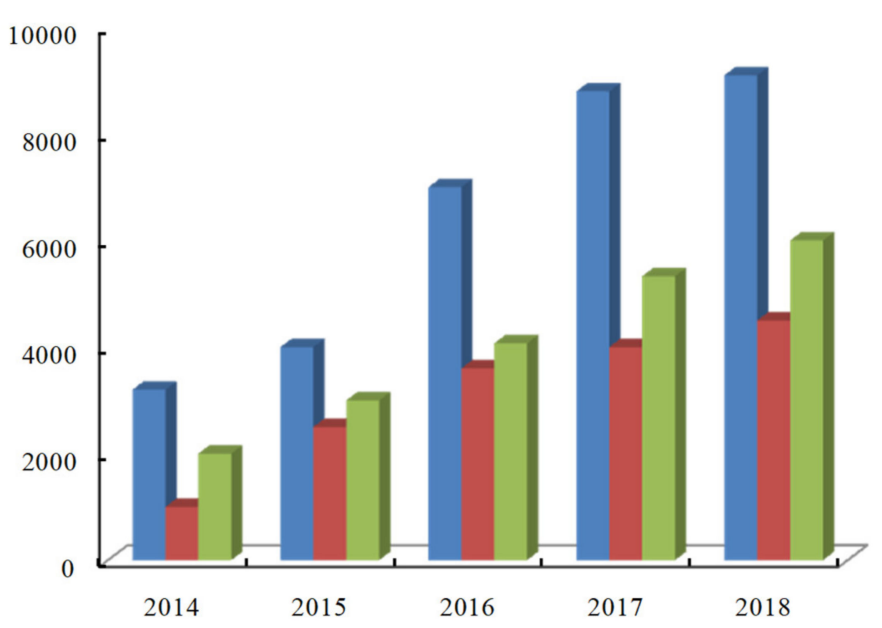

a

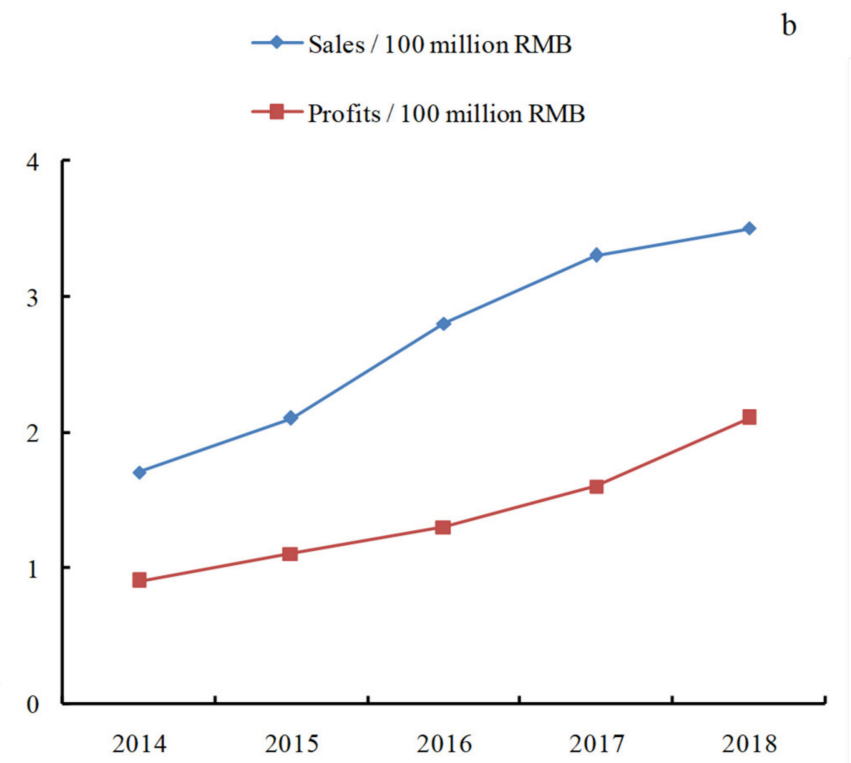

Figure 4. Changes in (a) wine production and sales and (b) wine sale and profits over 2014-2018. Data source: Hongsibu District Natural and Resources Bureau of Wuzhong Municipality, and Hongsibu District Agriculture and Rural Affairs Bureau of Wuzhong Municipality).

\subsection{Comprehensive Benefits of Wine Industry Development}

By comparing the first-level indicators, we constructed an evaluation matrix, determined the relative weights of the indicators (Figure 5a), and tested the matrix's consistency. Here, we obtained a consistency ratio (CR) of $0.065(<0.1)$, indicating that the evaluation matrix had a satisfactory consistency. The highest weight of the first-level indicators was economic benefits, followed by ecological benefits (Figure 5a).

We then compared the second-level indicators by constructing an evaluation matrix, determining the relative weights (Figure $5 b$ ), and testing its consistency. The CR here was also $<0.1$, indicating that the evaluation matrix had a satisfactory consistency. The secondary indicators with the highest and lowest weights were wine contributes to chateau's income and subsidies of industrial development environment, respectively (Figure 5b). 

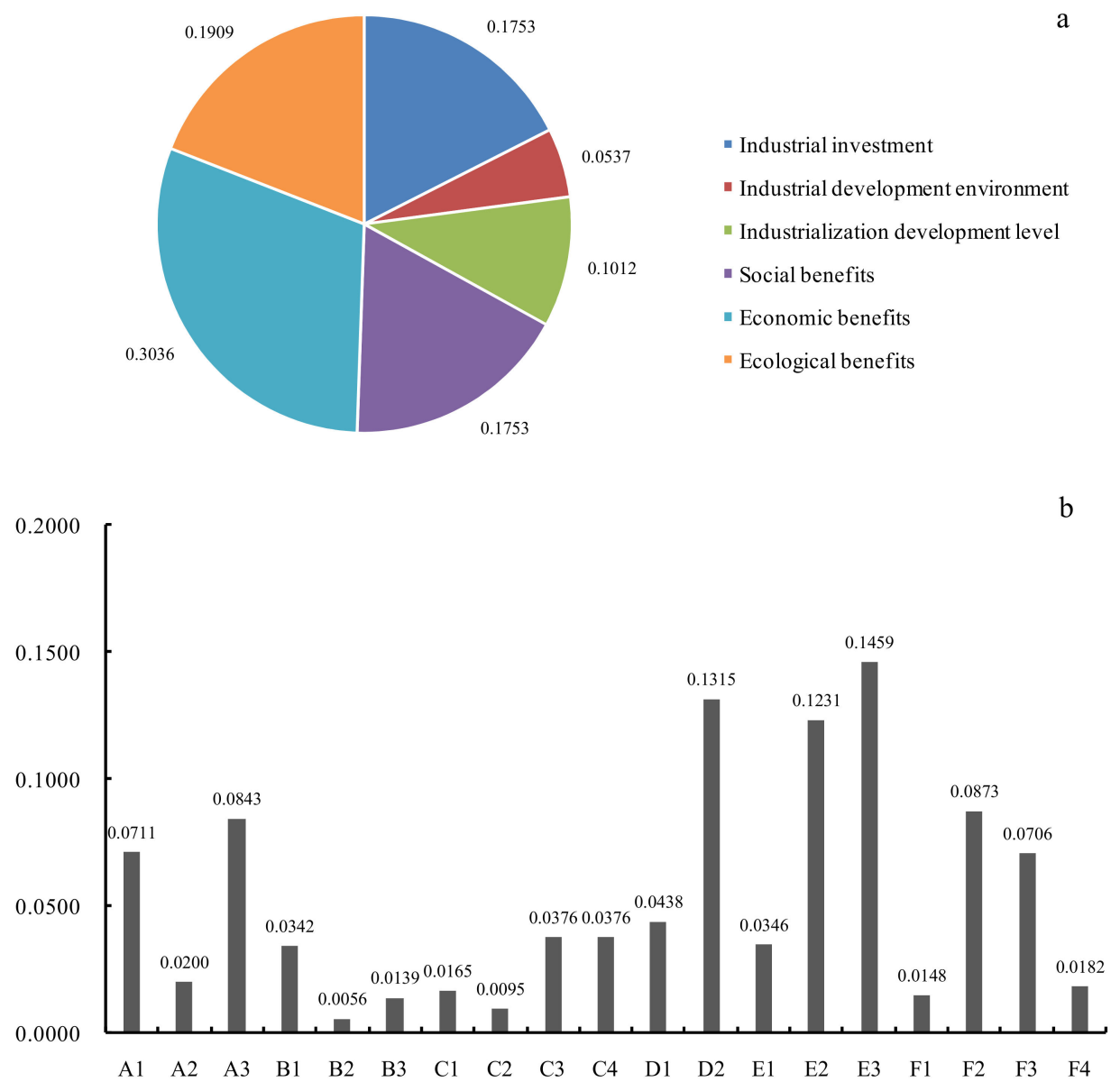

Figure 5. Weights of (a) first-level and (b) second-level indicators.

Comprehensive benefits of the wine industry for desertification control reached $81.85 \%$; thus, the wine industry has an important role in combating desertification. The results of the investment analysis demonstrated that the overall investment of the wine industry is large. Specifically, the industrial investment was better than the industrial development environment. The standardized score of the labor input per unit area, that of the amount of fertilizer per unit area, and that of the planting rate were $79.58 \%, 92.42 \%$, and $81.30 \%$, respectively (Table 4 ). In addition to government subsidies, the scores of industrial development environment were relatively low. Despite the efforts lavished by the government, the technical level of ordinary villagers remained very poor. The score of scientific and technological quality and that of labor quality were only $57.42 \%$ and $55.36 \%$, respectively. The scores of the industrialization development level were generally higher, with an enterprise processing rate of $86.21 \%$ and an enterprise sales ratio of $86.68 \%$ (Table 4).

From the perspective of social benefits, the development of the wine industry could drive $81.92 \%$ of local farmers to work and the poverty alleviation ratio reached $78.64 \%$. The social benefits of the wine industry were remarkable. The expected contribution of maximum fruiting reached $93.39 \%$ of grape growers' income and $83.51 \%$ of wine contributed to chateaus' income-indicating that the wine industry has an important role in local economic development. The reduction rates of desertified land and of windy and sandy days were $79.66 \%$ and $86.80 \%$, respectively. Thus, the wine industry has a significant and positive effect on desertification control (Table 4). 
Table 4. Actual and standard values and standardized score of each indicators.

\begin{tabular}{|c|c|c|c|c|c|c|c|}
\hline \multirow{2}{*}{$\begin{array}{l}\text { Secondary } \\
\text { Indicators }\end{array}$} & \multicolumn{3}{|c|}{ Actual Value (Av) } & \multicolumn{3}{|c|}{ Standard Value (Sv) } & \multirow{2}{*}{$\begin{array}{c}\text { Standardized } \\
\text { Score }\end{array}$} \\
\hline & $\begin{array}{c}\text { Sample } \\
\text { Size }\end{array}$ & $\begin{array}{c}\text { Average } \\
\text { Value }\end{array}$ & $\begin{array}{l}\text { Standard } \\
\text { Deviation }\end{array}$ & $\begin{array}{l}\text { Number of } \\
\text { Interviews }\end{array}$ & $\begin{array}{l}\text { Average } \\
\text { Value }\end{array}$ & $\begin{array}{l}\text { Standard } \\
\text { Deviation }\end{array}$ & \\
\hline A1 & 108 & 1.96 & 1.43 & 5 & 2.46 & 0.38 & $79.58 \%$ \\
\hline A2 & 108 & 4565.64 & 194.51 & 5 & 4940.00 & 135.65 & $92.42 \%$ \\
\hline A3 & 108 & 0.91 & 0.20 & 5 & 1.12 & 0.12 & $81.30 \%$ \\
\hline B1 & 108 & 0.47 & 0.10 & 5 & 0.82 & 0.09 & $57.42 \%$ \\
\hline B2 & 108 & 0.03 & 0.01 & 5 & 0.04 & 0.01 & $64.52 \%$ \\
\hline B3 & 108 & 0.70 & 0.28 & 5 & 1.27 & 0.45 & $55.36 \%$ \\
\hline $\mathrm{C} 1$ & 108 & 10.22 & 3.60 & 5 & 11.32 & 0.75 & $90.24 \%$ \\
\hline $\mathrm{C} 2$ & 108 & 0.92 & 0.22 & 5 & 1.18 & 0.42 & $78.08 \%$ \\
\hline $\mathrm{C} 3$ & 10 & 1.00 & 0.00 & 5 & 1.16 & 0.10 & $86.21 \%$ \\
\hline $\mathrm{C} 4$ & 10 & 0.83 & 0.15 & 5 & 0.96 & 0.04 & $86.68 \%$ \\
\hline D1 & 108 & 0.78 & 0.25 & 5 & 0.95 & 0.04 & $81.92 \%$ \\
\hline D2 & 108 & 0.66 & 0.47 & 5 & 0.84 & 0.05 & $78.64 \%$ \\
\hline E1 & 108 & 0.67 & 0.21 & 5 & 0.87 & 0.04 & $76.60 \%$ \\
\hline E2 & 108 & 0.86 & 0.34 & 5 & 0.92 & 0.04 & $93.39 \%$ \\
\hline E3 & 10 & 0.04 & 0.02 & 5 & 0.05 & 0.01 & $83.51 \%$ \\
\hline $\mathrm{F} 1$ & 108 & 0.46 & 0.10 & 5 & 0.60 & 0.13 & $75.93 \%$ \\
\hline $\mathrm{F} 2$ & 10 & 0.74 & 0.08 & 5 & 0.93 & 0.06 & $79.66 \%$ \\
\hline F3 & 10 & 0.71 & 0.07 & 5 & 0.82 & 0.06 & $86.80 \%$ \\
\hline $\mathrm{F} 4$ & 108 & 745.33 & 67.00 & 5 & 492.00 & 39.19 & $66.01 \%$ \\
\hline
\end{tabular}

Note: The data are based on a survey of the study region in 2019 (Source: Grape growers Surveys, 2019 [n = 108] and Chateaus Surveys, $2019[n=10])$.

\section{Discussion}

Over the last 10 years, wine industry development has been prioritized in Hongsibu, China, and the related development model has been optimized. The wine industry (referred to as vineyards) provide important ecosystem services [41] —an inference consistent with ours. Our results showed that the economic and social benefits of the wine industry are significant; moreover, this substantially increases the resident income. At the same time, the wine industry can effectively prevent desertification in poor areas, by increasing vegetation cover, reducing the number of windy and sandy days, and blocking dust and sand. Our results align with those of a study that showed that the branches of grapes cut in winter and continuously hung on wires form wind barriers, and this contributes to the wind and sand resistance of buried soil during the cold period [42].

Desertification management aims at restoring fragile ecological environments, improving people's living standards, and increasing resource use efficiency [43]. Viticulture makes full use of the mountain wasteland resources, and chateaus' greening and shelter forest construction greatly improves the economic forest cover. Wine industry development has thus played a positive role in improving the local ecological environment (Figure 3) and economic growth and in effectively controlling desertification-thus supporting our hypotheses.

\subsection{Ecological Value of the Wine Industry for Desertification Prevention}

The wine industry demonstrated a very large ecological value [44], possibly because of the following results: first, 13 winegrape varieties were employed, with a proportion of 4:1 between red and white cultivars; the varieties included Vitis vinifera 'Cabernet Sauvignon', $V$. vinifera 'Cabernet Franc', and V. Vinifera 'Chardonnay'. Second, the supporting role of the industrial development platform was significant, leading to remarkable results. In fact, the 30 wineries put into production $>40$ wine brands including Qianhongyu, Geruihong, and Zhonghe, and 87 wines won 139 awards in international and domestic wine competitions, such as the World Selection of Brussels and the International Wine Awards of Helan Mountains East. 
The total value of the ecosystem services of the wine industry was $6.13 \times 10^{8} \mathrm{RMB}$ (Table 2), indicating that the wine industry has an important ecological value. The reason is that vines are not only an economic forest, which produces fruits, but can also a characteristic green forest, which is conducive to the improvement of the ecological environment, mainly through carbon fixation and oxygen release [30], water conservation and watersaving and efficiency-enhancing [45], as well as atmospheric purification [30]. We found that food production is of great value because the region is an area conducive for growing wine grapes. It has sufficient sunshine, abundant heat, and a large daily temperature difference; these characteristics are conducive to the accumulation of sugar and very beneficial to the full development and maturity of the fruit. These superior conditions significantly improve food production [46,47].

In China's arid and semi-arid regions, vegetation and crop growth and survival are severely restricted by water resource availability [48]. This reduces water resource use and maximizes water use efficiency. Our current results demonstrated that vines have significant water-saving and synergistic values (Table 2). This is because the water resource use efficiency of wine grapes is higher than that of food and vegetable crops but their water consumption is lower: wine grapes require $3900 \mathrm{t} / \mathrm{ha}$ of water, whereas wolfberry requires $4200 \mathrm{t} / \mathrm{ha}$ and corn, wheat, and daylily require $5400 \mathrm{t} / \mathrm{ha}$. Moreover, when planting wine grapes, water can be saved through regulated deficit irrigation [49-51]. Therefore, we can infer that wine grapes are suitable for improving the ecological environment of arid regions.

\subsection{Economic and Social Benefits for Combating Desertification}

In northwest China, some residents cannot live normally in protecting the ecological environment [12]. Therefore, the management plan in this area is particularly focused on achieving economic benefits via desertification control. Here, we found that the wine industry has great economic value (Figure 4). Farmers sold wine grapes to increase income, whereas wine companies sold wines-thereby contributing to the sustainable development of the local society.

The wine industry generates significant economic benefits for desertification management. This is because the wine industry makes large investments and has a significant scale and economic value. Here, we found that the winegrape-growing area was continuously increasing. The fruit yield per unit area, the total fruit yield, and the planting income per unit area increased annually. This is consistent with the findings of other studies [52-54]. However, we also found that the output of wine grapes was relatively low $(<4500 \mathrm{~kg} / \mathrm{ha}$; Table 3). This is mainly because $>1980$ ha of the existing planted and preserved areas were added after 2010, and they are current not yet in the fruit-producing period. As such, the average yield was low in this study because the production potential was not realized fully. Furthermore, nearly 600 ha of old orchards had insufficient water and fertilizer input and low management level, and thus, the fruit yield did not meet the expected target. We may have, therefore, underestimated the economic value of the wine industry. The economic benefits of wineries and enterprises are relatively higher because of the enterprises management and low operating costs of chateaus. Those with a low efficiency have insufficient management systems and are affected by the wine market not being developed fully [55]. Here, wine sales and profits increased annually between 2014-2018 (Figure 4). This is because the technical problems of wine industry production were essentially resolved, the wine quality was generally recognized by the industry, and the wine consumption market expanded further. In other words, the large economic value of the wine industry provides an effective guarantee for desertification control.

The wine industry also generates significant social benefits for desertification management. The wine industry contributes to wealth generation and poverty alleviation, which can effectively address the employment of the poor population [56]: it has been reported to provide 60,000 jobs for ecological immigrants, with a total annual wage of nearly $2.0 \times 10^{8} \mathrm{RMB}$. As such, the wine industry is becoming a core industry to overcome 
migrant poverty-a conclusion that is consistent with the other studies [30]. Grape growers and chateaus have developed vine cultivations over a 7067-ha area. Assuming that one worker is required per $0.7 \mathrm{ha}$, the wine industry can generate a stable employment for 10,000 migrant workers with an annual per capita income of 15,000 RMB, thereby increasing of farmers' the annual income of $1.5 \times 10^{8} \mathrm{RMB}$ in this region.

\subsection{Comprehensive Benefits of the Wine Industry for Desertification Control}

Desertification control projects involve ecological, economic, and social aspects. During the entire governance process, attention should be paid to the coordinated development of economy, society, and ecology as well as the enhancement of comprehensive benefits. The quantitative analysis demonstrates that the wine industry generates positive, comprehensive benefits for desertification control (Table 4)-consistent with the previous results $[37,39]$. Therefore, the model of the comprehensive benefits of the wine industry on desertification control established in the current study can be used by other researchers.

An important factor that limits the comprehensive benefits of the wine industry for desertification control is the industrial development environment, such as low scientific and technological quality, which contributes to only a $57.42 \%$ value (Table 4 ). Here, we found that the wine production area needs to soil-bury the vines to ensure their safe wintering. However, the soil-burying process increases the cost of production, making it difficult to realize mechanized production $[57,58]$ — which leads to low technology levels. Another important factor restricting the industrial development environment is practitioners' education levels. More than $90 \%$ of the surveyed profit-making farmers had a high school or higher education level, whereas the loss-making farmers were mainly from illiterate groups or were elderly people or women. Accelerating the popularization of high-yield, high-quality, and efficient cultivation techniques for wine grapes is an important technical approach to improve the wine industry that has positive effect on desertification control.

Our study showed that the wine industry is characterized by large investments; a weak industrial development environment; a high industrialization level; and significant social, economic, and ecological benefits (Table 4). Our indicator system-established to assess the comprehensive benefits of the wine industry for desertification control—can reflect scientifically and comprehensively the objective reality and is applicable.

Through more than 40 years of desertification control, relatively stable ecological, economic, and social benefits have been achieved in Ningxia, and this has laid a good foundation for sustainable development $[1,2,59]$. Desertification management of the wine industry has generally been high (Table 4). This is because the policy orientation of the local government has helped the development of the wine industry and of the local economy, which in turn has played an important role in desertification control. Based on the results of the quantitative analysis, we propose the following recommendations to ensure strong desertification control: first, the government should provide as many technologies as possible to farmers through a combination of lectures as well as other means and increase the household registration rate of science and technology. Second, it the industrialization of the wine industry, the mode of operation of the enterprises and farmers, should be promoted to improve the comprehensive benefits of desertification control. Third, desertification control should be considered a systematic project involving the government, scientists, and farmers [11]. When constructing the project, various perfect guarantee systems should be established to coordinate the interests of all parties, so that economic, social, and ecological benefits is achieved in a comprehensive and balanced manner, with the coupling of the ecological and economic systems enhanced.

\section{Conclusions}

The development plan of Hongsibu's wine industry was established on the premise of "small winery and big industry" [60], which is in line with the development model of the wine industry. In summary, the wine industry (i.e., vineyards) has important ecosystem service functions. The wine industry has the attributes of an economical industry, with the 
ability to provide income increase and poverty alleviation to the growers and solve the livelihood problem of the poor residents in sandy areas. The wine industry is of a great value to combating desertification, especially for increasing the coverage of local economic forests and effectively changing the harsh natural environment of desertification areas. The development of the wine industry can be an effective approach for the government's ecological management department to formulate policies. Generally, the development of local specialty industries can help combat desertification in impoverished areas effectively, thus providing solutions to the dual pressures of poverty and environmental degradation, as well as providing a method of sustainable development worldwide.

Supplementary Materials: The following are available online at https://www.mdpi.com/article/10 .3390/su13105654/s1, Table S1: The calculation formulas and methods of ecosystem services.

Author Contributions: All authors contributed significantly to this manuscript. Conceptualization, L.Z.; methodology, L.Z. and T.X.; software, L.Z.; investigation, L.Z. and Z.W.; data curation, F.G., R.W. and Y.W. writing — original draft preparation, L.Z.; writing — review and editing, F.G. and X.H.; supervision, H.L. and H.W.; funding acquisition, H.L. and H.W.; All authors have read and agreed to the published version of the manuscript.

Funding: This study was supported by the National Key Research and Development Project (2019YFD1002500), Key Research and Development Project of Shaanxi Province (2020ZDLNY07-08).

Data Availability Statement: Data is contained within the article or Amentary Material.

Acknowledgments: We thank Jianhua Liu (Hongsibu District Agriculture and Rural Affairs Bureau of Wuzhong Municipality) for the wine industry development status of Hongsibu. We also appreciate Wei Yang (Hongsibu District Natural and Resources Bureau of Wuzhong Municipality) for suggestions and useful help in the investigation.

Conflicts of Interest: The authors declare no competing financial interests.

\section{References}

1. An, H.; Li, Q.L.; Yan, X.; Wu, X.Z.; Liu, R.T.; Fang, Y. Desertification control on soil inorganic and organic carbon accumulation in the topsoil of desert grassland in Ningxia, northwest China. Ecol. Eng. 2019, 127, 348-355. [CrossRef]

2. Chen, X.H.; Duan, Z.H. Changes in soil physical and chemical properties during reversal of desertification in Yanchi County of Ningxia Hui autonomous region, China. Environ. Geol. 2009, 57, 975-985. [CrossRef]

3. Mitchell, D.J.; Fullen, M.A.; Trueman, I.C.; Fearnehough, W. Sustainability of reclaimed desertified land in Ningxia, China. J. Arid Environ. 1998, 39, 239-251. [CrossRef]

4. Balmford, A.; Bruner, A.; Cooper, P.; Costanza, R.; Farber, S.; Green, R.E.; Jenkins, M.; Jefferiss, P.; Jessamy, V.; Madden, J.; et al. Economic Reasons for Conserving Wild Nature. Science 2002, 297, 950-953. [CrossRef]

5. He, M.Z.; Zheng, J.G.; Li, X.R.; Qian, Y.L. Environmental factors affecting vegetation composition in the Alxa Plateau, China. J. Arid Environ. 2007, 69, 473-489. [CrossRef]

6. Jiang, C.; Liu, J.G.; Zhang, H.Y.; Zhang, Z.D.; Wang, D.W. China's progress towards sustainable land degradation control: Insights from the northwest arid regions. Ecol. Eng. 2019, 127, 75-87. [CrossRef]

7. Miao, L.J.; Moore, J.C.; Zeng, F.J.; Lei, J.Q.; Ding, J.L.; He, B.; Cui, X.F. Footprint of Research in Desertification Management in China. Land Degrad. Dev. 2015, 26, 450-457. [CrossRef]

8. Wang, X.H.; Lu, C.H.; Fang, J.F.; Shen, Y.C. Implications for development of grain-for-green policy based on cropland suitability evaluation in desertification-affected north China. Land Use Policy 2007, 24, 417-424. [CrossRef]

9. Zhao, H.L.; Cui, J.Y.; Zhou, R.L.; Zhang, T.H.; Zhao, X.Y.; Drake, S. Soil properties, crop productivity and irrigation effects on five croplands of Inner Mongolia. Soil Till. Res. 2007, 93, 346-355. [CrossRef]

10. Zhang, Z.H.; Huisingh, D. Combating desertification in China: Monitoring, control, management and revegetation. J. Clean. Prod. 2018, 182, 765-775. [CrossRef]

11. Feng, Q.; Tian, Y.Z.; Yu, T.F.; Yin, Z.L.; Cao, S.X. Combating desertification through economic development in northwestern China. Land Degrad. Dev. 2019, 30, 910-917. [CrossRef]

12. Cao, S.X.; Zhong, B.L.; Yue, H.; Zeng, H.S.; Zeng, J.H. Development and testing of a sustainable environmental restoration policy on eradicating the poverty trap in China's Changting County. Proc. Natl. Acad. Sci. USA 2009, 106, 10712-10716. [CrossRef] [PubMed]

13. Chen, Y.; Tang, H. Desertification in north China: Background, anthropogenic impacts and failures in combating it. Land Degrad. Dev. 2005, 16, 367-376. [CrossRef] 
14. Sun, D.F.; Yu, X.Q.; Liu, X.N.; Li, B.G. A new artificial oasis landscape dynamics in semi-arid Hongsipu region with decadal agricultural irrigation development in Ning Xia, China. Earth Sci. Inform. 2016, 9, 21-33. [CrossRef]

15. Yang, B.H.; Yao, H.; Zhang, J.X.; Li, Y.Q.; Ju, Y.L.; Zhao, X.F.; Sun, X.Y.; Fang, Y.L. Effect of regulated deficit irrigation on the content of soluble sugars, organic acids and endogenous hormones in Cabernet Sauvignon in the Ningxia region of China. Food Chem. 2020, 312, 126020. [CrossRef]

16. Gougeon, L.; Da Costa, G.; Le Mao, I.; Ma, W.; Teissedre, P.-L.; Guyon, F.; Richard, T. Wine analysis and authenticity using 1H-NMR metabolomics data: Application to Chinese wines. Food Anal. Methods 2018, 11, 3425-3434. [CrossRef]

17. Li, Z.; Pan, Q.H.; Jin, Z.M.; Mu, L.; Duan, C.Q. Comparison on phenolic compounds in Vitis vinifera cv. Cabernet Sauvignon wines from five wine-growing regions in China. Food Chem. 2011, 125, 77-83. [CrossRef]

18. Sun, Y.L.; Liu, Q.Z.; Xi, B.; Dai, H.J. Study on the regulation of anthocyanin biosynthesis by exogenous abscisic acid in grapevine. Sci. Hortic. 2019, 250, 294-301. [CrossRef]

19. Li, L.X.; Sun, B.S. Grape and wine polymeric polyphenols: Their importance in enology. Crit. Rev. Food Sci. Nutr. 2019, 59, 563-579. [CrossRef] [PubMed]

20. Marsal, J.; Mata, M.; del Campo, J.; Arbones, A.; Vallverdú, X.; Girona, J.; Olivo, N. Evaluation of partial root-zone drying for potential field use as a deficit irrigation technique in commercial vineyards according to two different pipeline layouts. Irrig. Sci. 2008, 26, 347-356. [CrossRef]

21. Zhang, Q.T.; Wang, S.P.; Li, L.; Inoue, M.; Xiang, J.; Qiu, G.Y.; Jin, W.B. Effects of mulching and sub-surface irrigation on vine growth, berry sugar content and water use of grapevines. Agric. Water Manag. 2014, 143, 1-8. [CrossRef]

22. Wang, S.; Li, H.; Wang, H. Wind erosion prevention effect of suspending shoots on wires after winter pruning in soil-burying zones over-wintering. Trans. Chin. Soc. Agric. Eng. 2015, 31, 206-212.

23. Rusch, A.; Delbac, L.; Thiéry, D. Grape moth density in Bordeaux vineyards depends on local habitat management despite effects of landscape heterogeneity on their biological control. J. Appl. Ecol. 2017, 54, 1794-1803. [CrossRef]

24. Wang, X.Q.; Xie, X.L.; Chen, N.; Wang, H.; Li, H. Study on current status and climatic characteristics of wine regions in China. Vitis 2018, 57, 9-16.

25. Li, H.; Wang, H. Extremely simplified grapevine cultivation. Sino-Overseas Grapevine Wine 2020, 4, 47-51.

26. Ma, C.; Wang, X.B.; Zhang, W.H. A relict habitat became an isolated habitat in the Luoshan Nature Reserve from 1977 to 2017 : Natural or man-made disaster? Nat. Resour. Forum 2019, 43, 164-180. [CrossRef]

27. Garcia, L.; Celette, F.; Gary, C.; Ripoche, A.; Valdés-Gómez, H.; Metay, A. Management of service crops for the provision of ecosystem services in vineyards: A review. Agric. Ecosyst. Environ. 2018, 251, 158-170. [CrossRef]

28. Guo, W.H.; Kang, S.Z.; Li, F.S. Variation of NEE and its controlling factors in a vineyard of arid region of northwest China. Atmos. Environ. 2014, 84, 349-354. [CrossRef]

29. Li, T.; Cui, Y.H.; Liu, A.G. Spatiotemporal dynamic analysis of forest ecosystem services using "big data": A case study of Anhui province, central-eastern China. J. Clean. Prod. 2017, 142, 589-599. [CrossRef]

30. Song, Z.W.; Sun, M.Y.; Yang, R.J.; Dou, G.Y.; Zhang, Y.; Zhang, L. Evaluation of ecosystem service value of the grape industry at the eastern foot of Helan Mountain, Ningxia, China. J. Appl. Ecol. 2019, 30, 979-985.

31. Wei, H.L.; Qi, Y.J. Estimation and analysis of forest ecosystem services value: Case study in Baishuijiang National Nature Reserve in Gansu, western China. J. Bejing For. Univ. 2016, 38, 74-82.

32. Rosas-Ramos, N.; Baños-Picón, L.; Tobajas, E.; De Paz, V.; Tormos, J.; Asís, J.D. Value of ecological infrastructure diversity in the maintenance of spider assemblages: A case study of Mediterranean vineyard agroecosystems. Agric. Ecosyst. Environ. 2018, 265, 244-253. [CrossRef]

33. Wang, L.; Liu, J.M.; Wang, L.E.; Zhu, H.; Lin, J. Tourism resource assessment and spatial analysis of wine tourism development: A case study of the eastern foothills of China's Helan Mountains. J. Mt. Sci. 2018, 15, 645-656. [CrossRef]

34. Ferrari, V.; Taffarel, S.R.; Espinosa-Fuentes, E.; Oliveira, M.L.; Saikia, B.K.; Oliveira, L.F. Chemical evaluation of by-products of the grape industry as potential agricultural fertilizers. J. Clean. Prod. 2019, 208, 297-306. [CrossRef]

35. Rigby, D.; Woodhouse, P.; Young, T.; Burton, M. Constructing a farm level indicator of sustainable agricultural practice. Ecol. Econ. 2001, 39, 463-478. [CrossRef]

36. Zhao, F.J.; Wang, Y.J.; Jiang, Z.D. County-level walnut industry development evaluation system and its application. Issues For. Econ. 2010, 30, 447-451.

37. Zhu, H.J.; Yao, S.B. Study on the coupling process of ecological economic system of desertification control in the Ningxia Hui Autonomous Region. Sci. Tech. Manag. Res. 2015, 35, 242-245.

38. Sun, L.F. Structure and evaluation on indicators system of sustainable development of Xinjiang featured forestry and fruit industry. Xinjiang Agric. Sci. 2009, 46, 678-685.

39. Zhu, H.J. Study on Synthetic Benefit Evaluation on Desertification Control in Ningxia Hui Autonomous Region; Northwest Agriculture \& Forestry University: Shaanxi, China, 2015; Chapter VII; pp. 80-89.

40. Geng, Z.Q.; Zhao, S.S.; Tao, G.C.; Han, Y.M. Early warning modeling and analysis based on analytic hierarchy process integrated extreme learning machine (AHP-ELM): Application to food safety. Food Control. 2017, 78, 33-42. [CrossRef]

41. Assandri, G.; Bogliani, G.; Pedrini, P.; Brambilla, M. Beautiful agricultural landscapes promote cultural ecosystem services and biodiversity conservation. Agric. Ecosyst. Environ. 2018, 256, 200-210. [CrossRef] 
42. Wang, R.; Sun, Q.; Chang, Q.R. Soil Types Effect on Grape and Wine Composition in Helan Mountain Area of Ningxia. PLoS ONE 2015, 10, e0116690. [CrossRef] [PubMed]

43. Sun, D.F.; Richard, D.; Li, B.G. Agricultural causes of desertification risk in Minqin, China. J. Environ. Manag. 2006, 79, 348-356.

44. Brunori, E.; Farina, R.; Biasi, R. Sustainable viticulture: The carbon-sink function of the vineyard agro-ecosystem. Agric. Ecosyst. Environ. 2016, 223, 10-21. [CrossRef]

45. Daane, K.M.; Hogg, B.N.; Wilson, H.; Yokota, G.Y. Native grass ground covers provide multiple ecosystem services in Californian vineyards. J. Appl. Ecol. 2018, 55, 2473-2483. [CrossRef]

46. Li, H.Y.; Zhang, X.Y.; Wang, J.; Zhang, L.; Yang, Y. Ecological suitability regionalization of wine grape with different ripening dates in Ningxia. Chin. J. Ecol. 2014, 33, 3120-3126.

47. Liu, N.; Qin, Y.; Song, Y.Y.; Tao, Y.S.; Sun, Y.; Liu, Y.L. Aroma composition and sensory quality of Cabernet Sauvignon wines fermented by indigenous saccharomyces cerevisiae strains in the Eastern Base of the Helan Mountain, China. Int. J. Food Prop. 2016, 19, 2417-2431. [CrossRef]

48. Li, S.Y.; Tang, Q.L.; Lei, J.Q.; Xu, X.W.; Jiang, J.; Wang, Y.D. An overview of non-conventional water resource utilization technologies for biological sand control in Xinjiang, northwest China. Environ. Earth Sci. 2015, 73, 873-885. [CrossRef]

49. Ayars, J.E.; Abrisqueta, I.; Parry, C.; Perry, A.; McElrone, A.J. Water Management of Irrigated Cabernet Sauvignon Grapevines in Semi-Arid Areas. Am. J. Enol. Vitic. 2017, 68, 458-467. [CrossRef]

50. Savi, T.; Petruzzellis, F.; Martellos, S.; Stenni, B.; Borgo, A.D.; Zini, L.; Lisjak, K.; Nardini, A. Vineyard water relations in a karstic area: Deep roots and irrigation management. Agric. Ecosyst. Environ. 2018, 263, 53-59. [CrossRef]

51. Wang, R.; Yan, P.K.; Sun, Q.; Su, B.F.; Zhang, J.X. Effects of regulated deficit irrigation on the growth and berry composition of Cabernet Sauvignon in Ningxia. Int. J. Agric. Biol. Eng. 2019, 12, 102-109. [CrossRef]

52. Teslić, N.; Vujadinović, M.; Ruml, M.; Ricci, A.; Vuković, A.; Parpinello, G.P.; Versari, A. Future climatic suitability of the Emilia-Romagna (Italy) region for grape production. Reg. Environ. Chang. 2018, 19, 599-614. [CrossRef]

53. Niles, M.T.; Garrett, R.D.; Walsh, D. Ecological and economic benefits of integrating sheep into viticulture production. Agron. Sustain. Dev. 2017, 38, 1. [CrossRef]

54. Schultz, H.R. Global Climate Change, Sustainability, and Some Challenges for Grape and Wine Production. J. Wine Econ. 2016, 11, 181-200. [CrossRef]

55. Duan, B.; Arcodia, C.; Ma, E.; Hsiao, A. Understanding wine tourism in China using an integrated product-level and experience economy framework. Asia Pac. J. Tour. Res. 2018, 23, 949-960. [CrossRef]

56. Figueiredo, V.; Franco, M. Wine cooperatives as a form of social entrepreneurship: Empirical evidence about their impact on society. Land Use Policy 2018, 79, 812-821. [CrossRef]

57. Xue, T.T.; Han, X.; Zhang, H.J.; Wang, Y.; Wang, H.; Li, H. Effects of a biodegradable liquid film on winter chill protection of winegrape cultivars. Sci. Hortic. 2019, 246, 398-406. [CrossRef]

58. Yang, S.M.; She, H.Y.; Yang, S.C.; Zhu, X.J.; Chen, Y.; Li, J.H.; Li, M.Q. Design and experimental validation of improved grapevine burying machine. Int. J. Agric. Biol. Eng. 2018, 11, 95-100. [CrossRef]

59. Li, J.Y.; Yang, X.C.; Jin, Y.X.; Yang, Z.; Huang, W.G.; Zhao, L.N.; Gao, T.; Yu, H.D.; Ma, H.L.; Qin, Z.H.; et al. Monitoring and analysis of grassland desertification dynamics using Landsat images in Ningxia, China. Remote Sens. Environ. 2013, 138, 19-26. [CrossRef]

60. Li, H.; Wang, H. The new model of Chinese wine industry development. Liquor Mak. Sci. Technol. 2010, 198, 99-101. 